\title{
A Window into the Heterogeneity of Human Cerebrospinal Fluid A $\beta$ Peptides
}

\author{
Roberta Ghidoni, ${ }^{1}$ Anna Paterlini, ${ }^{1}$ Valentina Albertini, ${ }^{1}$ Elena Stoppani, ${ }^{1}$ \\ Giuliano Binetti, ${ }^{2}$ Kjell Fuxe, $^{3}$ Luisa Benussi, $^{2}$ and Luigi F. Agnati ${ }^{4}$
}

\author{
${ }^{1}$ Proteomics Unit, IRCCS “Centro S. Giovanni di Dio-FBF”, 25125 Brescia, Italy \\ ${ }^{2}$ NeuroBioGen Lab-Memory Clinic, IRCCS “Centro S. Giovanni di Dio-FBF”, 25125 Brescia, Italy \\ ${ }^{3}$ Department of Neuroscience, Karolinska Institutet, 17177 Stockholm, Sweden \\ ${ }^{4}$ IRCCS San Camillo, Lido VE, 30126 Venice, Italy
}

Correspondence should be addressed to Roberta Ghidoni, rghidoni@fatebenefratelli.it

Received 1 June 2011; Revised 27 June 2011; Accepted 30 June 2011

Academic Editor: Thomas Van Groen

\begin{abstract}
Copyright (c) 2011 Roberta Ghidoni et al. This is an open access article distributed under the Creative Commons Attribution License, which permits unrestricted use, distribution, and reproduction in any medium, provided the original work is properly cited.
\end{abstract}

\begin{abstract}
The initiating event in Alzheimer's disease $(\mathrm{AD})$ is an imbalance in the production and clearance of amyloid beta $(\mathrm{A} \beta)$ peptides leading to the formation of neurotoxic brain $A \beta$ assemblies. Cerebrospinal Fluid (CSF), which is a continuum of the brain, is an obvious source of markers reflecting central neuropathologic features of brain diseases. In this review, we provide an overview and update on our current understanding of the pathobiology of human CSF A $\beta$ peptides. Specifically, we focused our attention on the heterogeneity of the CSF A $\beta$ world discussing (1) basic research studies and what has been translated to clinical practice, (2) monomers and other soluble circulating $\mathrm{A} \beta$ assemblies, and (3) communication modes for $\mathrm{A} \beta$ peptides and their microenvironment targets. Finally, we suggest that $\mathrm{A} \beta$ peptides as well as other key signals in the central nervous system (CNS), mainly involved in learning and hence plasticity, may have a double-edged sword action on neuron survival and function.
\end{abstract}

\section{Introduction}

The "amyloid cascade hypothesis" suggests that the initiating event in Alzheimer's disease (AD) is an imbalance in the production and clearance of amyloid beta $(\mathrm{A} \beta)$ peptides leading to the formation of neurotoxic soluble and insoluble brain $\mathrm{A} \beta$ assemblies $[1,2]$. Thus, $\mathrm{A} \beta$ has become a major therapeutic target, with various anti- $\mathrm{A} \beta$ strategies being pursued [3]. Biologically, monomeric $A \beta$ is formed through the enzymatic cleavage of the transmembrane amyloid precursor protein (APP). The discovery of the APP gene was followed by the identification of missense mutations associated with familial, early-onset AD. These mutations are found in and around the A $\beta$ region of APP (http://www.molgen.ua.ac.be/ $A D m u t a t i o n s /)$ and affect the production or aggregation properties of $A \beta$. The physiopathological processing of APP involves various proteolytic activities leading to a complex set of $A \beta$ fragments. Full-length $A \beta 1-40$ and $A \beta 1-42$ peptides are generated by sequential proteolytic processing involving $\beta$ and $\gamma$-secretases on APP [4]. These peptides (i.e., A $\beta 1$ $40, \mathrm{~A} \beta 1-42$ ) have been the dominant focus of research, but it is well established that $\mathrm{N}$ - and C-terminally truncated or modified forms of $\mathrm{A} \beta$ peptides also exist in $\mathrm{AD}$ brains [5-9]. The detection of $N$-terminal truncated $A \beta$ peptides (especially $A \beta x-42$ ) in young Down's syndrome and in preclinical AD brains suggests that the amino-truncated species are implicated in the very first step of amyloidosis [1012]. These forms are generated mainly by cleavage of APP between residues 16 and 17 of the $\mathrm{A} \beta$ domain via the $\alpha$ secretase and by the alternative $\beta^{\prime}$ cleavage of APP triggered by the $\beta$-secretase $\beta$-site APP-cleaving enzyme (BACE) 1 [1315]. Heterogeneity at the $C$-terminus of $A \beta$ also contributes to the molecular variety of $A \beta$ peptides; according to some reports, due to its imprecise cleavage specificity, $\gamma$-secretase generates $\mathrm{A} \beta$ peptides of variable length at the $\mathrm{C}$-terminus [16]. Recently, $\gamma$-secretase has also been shown to cleave near the cytoplasmic membrane boundary of APP, called $\varepsilon$-site cleavage [17]. In addition, it has been recently demonstrated 
that the combined activity of $\alpha$ - and $\beta$-secretases may generate the shortest forms (i.e., $\mathrm{A} \beta$ 1-15, $\mathrm{A} \beta$ 1-16) of $\mathrm{C}$ terminally truncated $\mathrm{A} \beta$ peptides [18]. Body fluids, such as cerebrospinal fluid (CSF), plasma, serum, or urine represent a cellular protein-rich information reservoir that contains traces of what has been secreted into these fluids. In particular, CSF, which is a continuum of the brain, is an obvious source of markers reflecting central neuropathologic features of the brain diseases.

This review provides an overview and update on our current understanding of the pathobiology of human CSF A $\beta$ peptides.

\section{CSF A $\beta$ Peptides in Translational Research}

Has knowledge on pathobiology of $\mathrm{A} \beta$ been somehow translated to clinical practice? The criteria for the clinical diagnosis of AD were established by the National Institute of Neurological and Communicative Disorders and Stroke (NINCDS) and the Alzheimer's Disease and Related Disorders Association (ADRDA) workgroup in 1984 [19]. However, in the intervening 27 years, important advances in our understanding of $\mathrm{AD}$, in our ability to detect the pathophysiological process of $\mathrm{AD}$, and changes in conceptualization regarding the clinical spectrum of the disease have occurred $[20,21]$.

The revised diagnostic criteria proposed in 2011 by the National Institute of Aging and the Alzheimer's Association workgroup include the incorporation of biomarkers of the underlying disease state and formalization of different stages of disease- "preclinical AD," "mild cognitive impairment (MCI) due to $\mathrm{AD}$," and "AD dementia"-in the diagnostic criteria [22-24]. Biomarkers are parameters (physiological, biochemical, anatomic) that can be measured in vivo and that reflect specific features of disease-related pathophysiological processes. In recent years, a number of reports have utilised specific protein/peptide quantitation techniques such as ELISA to study the levels of selective moieties in CSF as biomarkers of this neurodegenerative disorder. The three major alterations in $\mathrm{AD}$ brain are extracellular amyloid plaques, axonal degeneration, and intraneuronal tangles, which can be monitored with the CSF biomarkers A $\beta 1-42$, total tau, and phosphorylated tau, respectively. The onset and progression of AD biomarkers likely follows an ordered temporal pattern. Biomarkers of $\mathrm{A} \beta$ amyloid are indicative of initiating or upstream events which seem to be most dynamic (i.e., deviate most significantly from normal) before clinical symptoms. Biomarkers of neuronal injury and neuronal dysfunction are indicative of downstream pathophysiological processes which become dynamic later. There is evidence suggesting that combined assessment of CSF tau and A $\beta 1-42$ have high diagnostic accuracy for established AD [25]. They may also be used to identify $\mathrm{AD}$ before onset of dementia at the stage of MCI, as shown in both mono-center and large-scale heterogeneous multicenter studies [26-30]. Since CSF levels of the shorter $A \beta 1-40$ isoform are unchanged or increased in $\mathrm{AD}$, it has been proposed that measurement of the $\mathrm{A} \beta 1$ $42 / \mathrm{A} \beta 1-40$ ratio might be superior to $\mathrm{A} \beta 1-42$ alone [3134]. Of note, $A \beta 1-42$ is associated with impairment of cognitive function from a potentially early to a later disease phase [35-37]. Decreased CSF A $\beta 1-42$ is also seen in other neurodegenerative disorders [38]. Recent studies have shown associations between shorter forms of $\mathrm{A} \beta$ peptides and specific dementias: decreased $\mathrm{A} \beta 1-38$ levels correlated with frontotemporal dementia [39] and A $\beta 1-37$ with Lewy Body dementia [40]. Thus, the detection of the whole spectrum of $\mathrm{A} \beta$ peptides in the CSF could be useful in order to improve early differential diagnosis.

\section{The Large Family of CSF A $\beta$ Peptides: The Mass Spectrometry-Based Detection}

The predominant protein component of amyloid plaques are strongly aggregating peptides with an approximate molecular mass of $4 \mathrm{kDa}$. The main plaques component is the 42 amino acid isoform of $\mathrm{A} \beta$; this isoform is highly hydrophobic and forms oligomers and fibrils that accumulate in extracellular plaques [41]. The deposition of the peptide in plaques is considered the underlying basis for the decrease in CSF A $\beta 1$ 42 levels seen in $\mathrm{AD}$ and incorporated in the new diagnostic criteria. In addition, other isoforms of $\mathrm{A} \beta$, for example, pyro $\mathrm{A} \beta 3-42, \mathrm{~A} \beta 4-42$, pyro $\mathrm{A} \beta 11-42, \mathrm{~A} \beta 17-42, \mathrm{~A} \beta 1-40$, and $\mathrm{A} \beta 11-40$ have been detected in the brains of sporadic $\mathrm{AD}$ and familial AD cases $[5-12,42-46]$. A $\beta$ peptides heterogeneity is observed also in the human CSF (see Table 1) [47-58]. The proteolytically processed $\mathrm{A} \beta$ peptides, however, are difficult to detect in the CSF-using standard methods, possibly because they comprise a heterogeneous set of both $\mathrm{N}$ - and C-terminally truncated peptides, some of which are present only at low levels. Many investigators used mass spectrometry (MS) for studying human CSF A $\beta$ peptides. MS allows for the detection of a variety of modified and truncated $\mathrm{A} \beta$ peptides, thus enabling a more detailed and unbiased analysis of fragments that may play a role in neurodegeneration. The two main approaches are (1) the use of preactivated chip arrays that allow coupling with specific antibodies combined with surface-enhanced laser desorption and ionization time-of-flight (SELDI-TOF) MS (2) immunoprecipitation combined with matrix-assisted laser desorption/ionization time-of-flight (MALDI-TOF) MS. An immunoproteomic approach-which combines specificity of $6 \mathrm{E} 10$ (against $\mathrm{A} \beta$ epitope 1-16) mAb capture with precision of spectral analysis (i.e., SELDI-TOF MS) — has recently been successfully used to analyze $\mathrm{A} \beta$ peptides in human CSF; Maddalena et al. [50] detected 9 C-terminally and $1 \mathrm{~N}$-terminally truncated $\mathrm{A} \beta$ peptides in CSF of $\mathrm{AD}$ patients and healthy controls subjects. while, with an analogous protocol, $10 \mathrm{~A} \beta$ fragments were found by Lewczuk et al. [55, 58]. Immunoprecipitation experiments employing 4G8 mAb and MALDI-MS analyses of $\mathrm{A} \beta$ peptides from $1 \mathrm{~mL}$ CSF revealed the presence of two previously unidentified $\mathrm{N}$-terminally truncated $\mathrm{A} \beta$ peptides (i.e., $\mathrm{A} \beta 11-30, \mathrm{~A} \beta 11-40$ ), along with a number of C-terminally truncated forms $[47,48]$. Since $6 \mathrm{E} 10$ and $4 \mathrm{G} 8 \mathrm{mAbs}$ bind different portions of $\mathrm{A} \beta$ sequence, we tested whether the combined use of these two mAbs could improve the capture of $\mathrm{N}$ and C-terminally truncated $\mathrm{A} \beta$ peptides; of note, applying this optimized immunoproteomic assaythat employs very low sample volume $(5 \mu \mathrm{L}$ of CSF for each 
TABle 1: Summary of A $\beta$ peptides in human CSF.

\begin{tabular}{|c|c|c|}
\hline $\mathrm{A} \beta$ Peptides & Theoretical mass* (Da) & Literature \\
\hline $\mathrm{A} \beta 1-12$ & 1424.61 & [47] \\
\hline $\mathrm{A} \beta 1-13$ & 1561.67 & {$[47-49]$} \\
\hline $\mathrm{A} \beta 2-14$ & 1583.70 & {$[50]$} \\
\hline $\mathrm{A} \beta 1-14$ & 1698.73 & {$[47-49]$} \\
\hline $\mathrm{A} \beta 1-15$ & 1826.78 & {$[47-49]$} \\
\hline $\mathrm{A} \beta 3-17$ & 1881.90 & {$[48]$} \\
\hline $\mathrm{A} \beta 2-17$ & 1952.94 & {$[48]$} \\
\hline $\mathrm{A} \beta 1-16$ & 1954.88 & {$[47-49]$} \\
\hline $\mathrm{A} \beta 1-17$ & 2067.96 & {$[47-52]$} \\
\hline $\mathrm{A} \beta 1-18$ & 2167.03 & {$[47-51]$} \\
\hline $\mathrm{A} \beta 11-30$ & 2212.11 & [47] \\
\hline $\mathrm{A} \beta 1-19$ & 2314.10 & {$[47-49,51,52]$} \\
\hline $\mathrm{A} \beta 1-20$ & 2461.17 & [47-49] \\
\hline $\mathrm{A} \beta 6-27$ & 2521.16 & {$[53]$} \\
\hline $\mathrm{A} \beta 11-34$ & 2608.39 & {$[53]$} \\
\hline $\mathrm{A} \beta 1-27$ & 3133.44 & {$[53]$} \\
\hline $\mathrm{A} \beta 11-40$ & 3150.68 & {$[47,51,54]$} \\
\hline $\mathrm{A} \beta 6-34$ & 3167.60 & {$[53]$} \\
\hline $\mathrm{A} \beta 1-28$ & 3261.53 & {$[47,48,53,55]$} \\
\hline$A \beta 6-35$ & 3298.63 & {$[53]$} \\
\hline $\mathrm{A} \beta 12-43$ & 3306.80 & {$[53]$} \\
\hline $\mathrm{A} \beta 10-40$ & 3313.74 & {$[51,54]$} \\
\hline $\mathrm{A} \beta 1-29$ & 3318.56 & {$[55]$} \\
\hline $\mathrm{A} \beta 11-42$ & 3334.80 & {$[51,54,56]$} \\
\hline $\mathrm{A} \beta 1-30$ & 3389.59 & {$[47-49,53]$} \\
\hline $\mathrm{A} \beta 11-43$ & 3435.85 & {$[53]$} \\
\hline $\mathrm{A} \beta 3-34$ & 3599.80 & {$[53]$} \\
\hline $\mathrm{A} \beta 1-33$ & 3672.78 & {$[47,49-51,54,55,57]$} \\
\hline $\mathrm{A} \beta 1-34$ & 3785.87 & {$[47,49-51,53-55,57]$} \\
\hline $\mathrm{A} \beta 1-35$ & 3916.91 & {$[51,53,57]$} \\
\hline $\mathrm{A} \beta 1-36$ & 4015.98 & {$[51]$} \\
\hline $\mathrm{A} \beta 1-37$ & 4073.00 & {$[47,49-51,54,55,57,58$} \\
\hline $\mathrm{A} \beta 1-38$ & 4130.02 & {$[47,49-51,53-55,57,58$} \\
\hline $\mathrm{A} \beta 1-39$ & 4229.09 & {$[47,49-51,54,55,57,58$} \\
\hline $\mathrm{A} \beta 1-40$ & 4328.16 & {$[47,49-51,53-55,57,58$} \\
\hline $\mathrm{A} \beta 1-42$ & 4512.28 & {$[47,49-51,54-58]$} \\
\hline A $\beta 3-44$ & 4526.33 & {$[58]$} \\
\hline $\mathrm{A} \beta 1-45$ or $\mathrm{A} \beta 2-46$ & 4825.48 or 4809.52 & {$[55]$} \\
\hline $\mathrm{A} \beta 3-47$ & 4851.56 & {$[58]$} \\
\hline
\end{tabular}

*The masses presented are the monoisotopic protonated molecules.

spot) - we detected a total of $15 \mathrm{~A} \beta$ peptides (12 C-terminally and $3 \mathrm{~N}$-terminally truncated forms) in human CSF [51].

In addition, we determined mass profiles of $\mathrm{A} \beta$ peptides in the CSF of patients carrying familial AD-associated mutations (i.e., APP T719P, PS1 P117L, and PS2 T122R); these mutations were associated with an overall reduction of $A \beta$ species. Interestingly, the APP T719P mutation unbalanced the relative proportion of $A \beta$ peptides with a reduction of $A \beta 1-40$ and $A \beta 1-42$ paralleled by an increase of $A \beta 1-38$ and
$\mathrm{A} \beta 10-40$ [54]. In accordance with these data, Portelius and coauthors [49] reported a reduction C-terminally truncated $\mathrm{A} \beta$ peptides in CSF of affected and unaffected subjects carrying PS1 A431E mutation. An unbalance of $A \beta$ isoforms was also detected in CSF of sporadic AD and MCI patients $[50,52,56,57]$. Interestingly, within a phase II clinical trial, it has been recently demonstrated that $\mathrm{A} \beta 1-14, \mathrm{~A} \beta 1-15$, and A $\beta 1-16$ are positive and very sensitive biomarkers for $\gamma$ secretase inhibition (even at doses that do not affect $A \beta 1-42$ or $A \beta 1-40$ ) [59]. Thus, $A \beta$ isoforms may be novel biomarkers to monitor the onset and progression of cognitive decline and the biochemical effect of disease-modifying drugs in $\mathrm{AD}$ clinical trials.

\section{Beyond A $\beta$ Monomers: CSF Circulating A $\beta$ Oligomers}

In the human brain it is likely that multiple $\mathrm{A} \beta$ assemblies, that are in dynamic equilibrium almost simultaneously, alter brain cell function and that different toxic effects may occur virtually concurrently in various regions of the cerebrum. Several lines of evidence have converged to demonstrate that soluble oligomers of $\mathrm{A} \beta$ may be responsible for synaptic dysfunction in $\mathrm{AD}$ animal models and in the brains of $\mathrm{AD}$ patients $[46,60,61]$. Small diffusible $A \beta$ oligomers have been shown to exert neurotoxic effects in cultured neurons [6264]. It has been hypothesized that such prefibrillar assemblies might also be neurotoxic in vivo since synaptic, electrophysiological, and behavioral changes have been well documented in young APP transgenic mice before plaque formation $[65,66]$. Accordingly, soluble $A \beta$ oligomers have been found to block, in vivo, hippocampal long-term potentiation (LTP), a synaptic correlate of memory and learning [6771]. Importantly, $A \beta$ immunotherapy can protect against the neuropathology and cognitive deficits observed in APP transgenic mice and also prevent the LTP inhibition induced by $\mathrm{A} \beta$ oligomers [68]. Soluble oligomeric $\mathrm{A} \beta$ has been shown to be present in human CSF [72-74]. Human derived soluble $\mathrm{A} \beta$ seems to have a pathophysiological role in the brain; the CSF-derived $A \beta$ dimers - and not the monomers-potently disrupt synaptic plasticity in vivo [75]. Of note, it has been reported that CSF circulating oligomers are increased in $\mathrm{AD}$ and MCI patients, and their levels are negatively correlated with Mini-Mental State Examination scores [76, 77]. Thus, an emerging strategy within the AD field is to use oligomeric $\mathrm{A} \beta$ as a possible biomarker/therapeutic target for the disease. The actual identity of the oligomer participating in $\mathrm{AD}$ pathogenesis remains elusive although several lines of evidence suggest that $\mathrm{AD}$-associated oligomers are primarily composed of $A \beta 42$. Nevertheless Gao and coworkers, using a novel misfolded protein assay, found an enrichment of $A \beta 40-$ containing oligomers in AD CSF [78] and suggested these assemblies as biomarker for early diagnosis of AD. Although $\mathrm{A} \beta$ oligomers are attractive $\mathrm{AD}$ biomarker candidates, several issues relating to these molecules persist. The levels of these $\mathrm{A} \beta$ species in CSF seem to be very low in comparison with $A \beta$ monomers and the precise molecular identity of these soluble toxins remains unsettled; thus more precise mass spectrometry analyses are needed in order to better 
characterize the molecular weight and composition of the most neurotoxic species. Furthermore, assays suitable for large clinical studies are still to be developed for these molecules. The development of conformation-sensitive antibody domains targeting the $\mathrm{A} \beta$ oligomers [79-83] is of great interest for research in this field. Targeting the pathological assemblies of $\mathrm{A} \beta$ with specific probes, for mechanistic studies, for intracellular imaging, or for therapeutic purposes, is therefore very important.

\section{A $\beta$ Peptides Are Double-Edged Sword Signals Transmitted Both via Volume and Wiring Transmission}

As discussed above, $\mathrm{A} \beta$ peptides have been regarded as the principal toxic factor in the neurodegeneration of $\mathrm{AD}$. Intense research effort has, therefore, been directed at determining their sources, activities, and fates, primarily with a view of preventing their formation or toxic actions, or promoting their degradation.

These are important studies and very promising ones for a better understanding of the pathogenesis of $\mathrm{AD}$. However, in our opinion, a crucial aspect is the discovery of the physiological role of these peptides.

Thus, the following points will be briefly discussed as far as the $\mathrm{A} \beta$ peptides are concerned:

(a) communication modes for these peptides, hence (volume transmission (VT)) versus (wiring transmission (WT)) versus (VT and WT);

(b) micro-environment where the targets for $\mathrm{A} \beta$ peptides are located, hence plasma membrane versus intracellular environment;

(c) possible physiological roles of $\mathrm{A} \beta$ peptides.

Finally, a previously published theoretical proposal [84] will be summarised since it can give a possible frame for interpreting otherwise contradictory data on $\mathrm{A} \beta$ peptides functions. The hypothesis is based on the concept that $\mathrm{A} \beta$ peptides as well as other key signals in the central nervous system (CNS) mainly involved in learning, and hence plasticity may have a double-edged sword action on neuron survival and function.

5.1. Communication Modes for A $\beta$ Peptides and Their Microenvironment Targets. It has been proposed that two main modes for intercellular communication are in operation in the CNS, namely, the VT and the WT [85].

The characteristics of the channel connecting two nodes of the network, that is, the cell source of the signal with the cell-target of the signal allow distinguishing the VT from the WT.

(i) VT is characterized by a channel with a poorly defined physical substrate and signal transmission takes place via diffusion (or vector migration) in the medium interposed between nodes. Recently, it has been shown that several messages can be sent via microvesicles (acting as protective containers hence like the bag of a roamer), dispatched into the extracellular space (ECS) and diffusing until the proper targets are reached [86-88].

Different types of microvesicles have been described, which are the result of specific cellular phenomena [86]. In particular, exosomes are microvesicles contained within a special class of membrane-bound organelles (endosomes), which can be released by fusion of the limiting membrane of the MVB with the plasma membrane.

(ii) WT is characterized by the transmission of the signal along a channel with a well-defined physical substrate; thus, a "wire" links the source node with the target node. Classically, in the case of neural networks, the WT-channel is formed by an axon and a chemical synapse.

However, two more subclasses of WT play a role in the CNS. The first one is represented by the well-characterized gap junctions, while the second one, the clear-cut in vivo demonstration of which has not yet been provided, is represented by the tunnelling nanotubes (TNTs) that are transient structures forming a "private" direct channel connecting two cells. They have a diameter of 50-200 $\mathrm{nm}$ and a length up to several cell diameters. Several in vitro studies demonstrated that these structures make possible the exchange of proteins, mtDNA, RNA, and whole organelles between cells [89]. It is interesting to note that $\mathrm{A} \beta$ peptides can be transmitted according to both VT and WT. Actually, it has been shown that these signals can use several possible modes of intercellular communication:

(i) the classical VT mode that is diffusion in the ECS [90-94],

(ii) the Roamer Type of VT that is diffusion via exosomes [95-99],

(iii) the TNT mode of WT [100].

The targets for the $\mathrm{A} \beta$ peptides are located both at the plasma membrane level $[101,102]$ and at intracellular level where they may exert an "intracrine function" $[95,103$, 104].

5.2. Possible Functional Roles of $A \beta$ Peptides. We completely agree with Pearson and Peers' view that $\mathrm{A} \beta$ peptides should have important physiological roles and may even be crucial for neuronal cell survival and CNS function. Thus, the view of $\mathrm{A} \beta$ being a purely toxic peptide requires a reevaluation [105]. In support of such a proposal, there are several papers, two of these will be cited since while the first one shows a role of $\mathrm{A} \beta$ peptides on learning [106], the other one opens a new field by giving evidence for a possible role of these peptides as antimicrobial agents [107].

Thus, it has been shown that, in contrast with its pathological role when accumulated, endogenous $A \beta$ in normal hippocampi mediates learning and memory formation probably via nicotinic acetylcholine receptors. Furthermore, hippocampal injection of picomolar concentrations of exogenous $\mathrm{A} \beta 1-42$ enhances memory consolidation. Hence, $\mathrm{A} \beta$ peptides, including $A \beta 1-42$, play an important physiological role in hippocampal memory formation. 


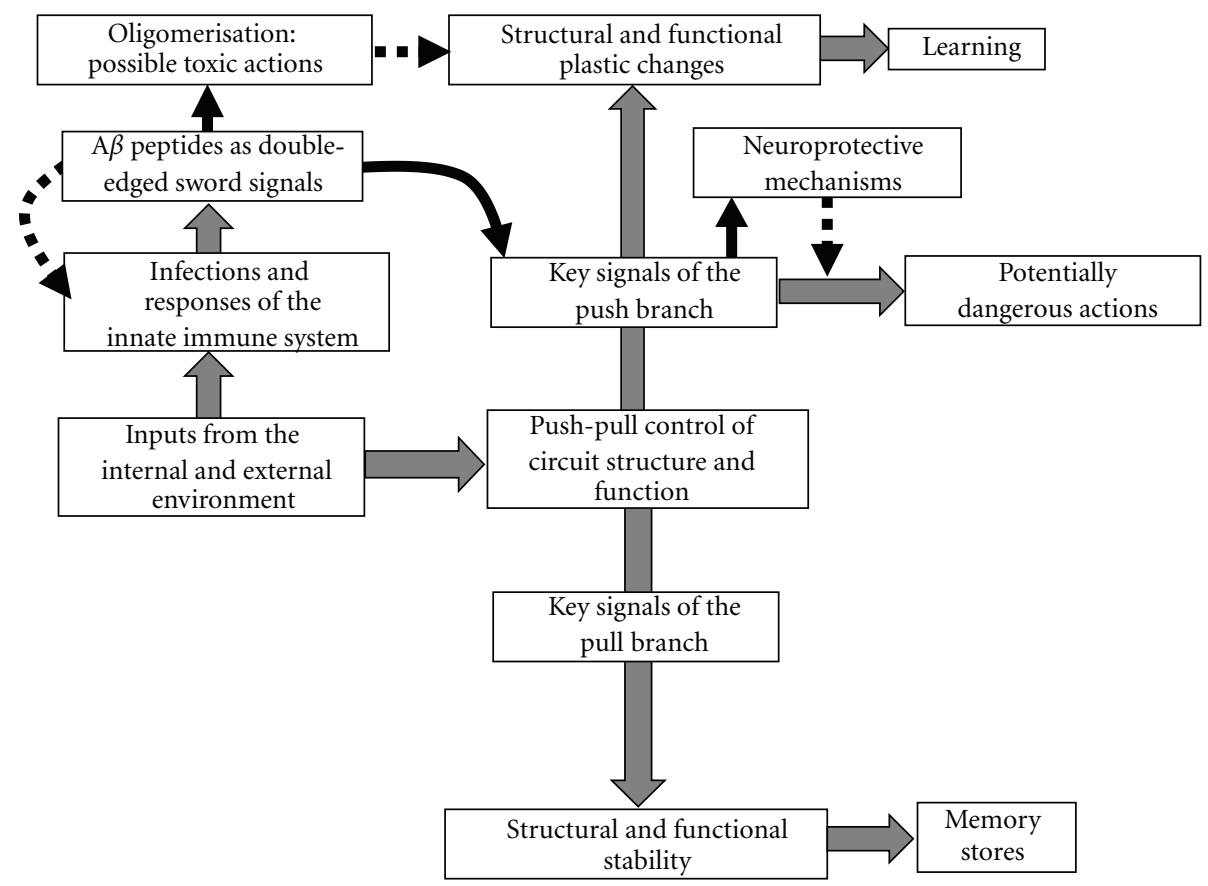

FIGURE 1: Schematic representation of the "Push and Pull Control" of structural and functional plasticity of neuronal circuits and how this control is related to learning processes (plastic changes of the circuits) and maintenance of the memory traces (stability of the circuits). The possible actions of $\mathrm{A} \beta$ peptides as double-edged sword signals are indicated. Broken arrows indicate reduction or inhibition.

As mentioned above, recently a new possible function for $\mathrm{A} \beta$ peptides has been demonstrated, namely, the antimicrobial action. Thus, it has been shown that many of the physiochemical and biological properties previously reported for $\mathrm{A} \beta$ are similar to those of a group of biomolecules collectively known as "antimicrobial peptides" (AMPs; also called "host defense peptides") which function in the innate immune system. These peptides are potent, broad-spectrum antibiotics that target several infective agents. In particular, the pleiotropic LL-37 peptide is a widely expressed archetypal AMP present also in humans that exhibits striking similarities to $\mathrm{A} \beta$, including a propensity to form cytotoxic soluble oligomers and insoluble fibrils with classical histochemical properties of tinctorial amyloid. Soscia et al. [107] findings reveal that $\mathrm{A} \beta$ exerts antimicrobial activity against eight common and clinically relevant microorganisms with a potency equivalent to, and in some cases greater than, LL-37. These findings obviously impose a great caution in developing future $\mathrm{AD}$ treatment strategies based on the drastic reduction of synthesis and levels of $\mathrm{A} \beta$ peptides.

\subsection{Double-Edged Sword Action of A $\beta$ Peptides on Neuron} Plasticity and Survival. More than one century ago, Tanzi proposed that learning processes in the CNS are basically due to plastic changes of neuronal networks [108].

As pointed out by Taylor and Gaze, neuronal plasticity allowing continuous CNS adaptation to the challenges of the environment plays a fundamental role not only for learning processes. Actually, plasticity in the nervous system means a patterned or ordered alteration in structure and function brought about by development, experience, or injury [109].
Thus, this definition mentions age, learning, and lesions as factors triggering out plasticity.

In this paper the concept is introduced that physiological processes (such as learning and memory) as well as repairable processes (such as those occurring after lesions or during ageing), being all rooted in CNS rearrangements, are competing for the brain plasticity [110], which exists as a fixed amount ("total brain plasticity capability," see [84]).

It has been demonstrated that some signals, such as excito-amino acids, $\mathrm{A} \beta$ peptides, and $\alpha$-synuclein ( $\alpha$-syn), are not only involved in information handling by the neuronal circuits, but also trigger out CNS plasticity [84]. It has also been shown that these signals are potentially dangerous possibly since, interalia, they force the neuronal circuits to move from one stable state towards a new state. Several mechanisms are put in action to protect neurons and glial cells from these potentially harmful signals and hence favouring the emergence of only their physiological functions. However, ageing and neurodegenerative diseases, on one side, increase the need of plasticity for the CNS repair but, on the other side, cause a reduction in the secretion of several trophic factors (e.g., BDNF and NGF) leading to a less effective neuroprotection and deficits in neural plasticity [111, 112].

Against this background, it has been shown that in ageing and neurodegenerative diseases functionally ambivalent (i.e., double-edged sword) signals such as A $\beta$ and $\alpha$-syn are secreted at a high rate possibly in the attempt of maximizing neuronal plasticity. It has been proposed that in the long run these peptides do not exert their possible physiological actions but on the contrary may favour neurodegenerative processes. 
Soscia et al. [107] have demonstrated that an increased $\mathrm{A} \beta$ generation/accumulation leading to $\mathrm{AD}$ pathology may be mediated by a response of the innate immune system to a perceived infection. This model is in agreement with data supporting a central role for neuroinflammation in AD neuropathology [113].

Thus, not only genetic factors may contribute to activation of the innate immune system by regulating $\mathrm{A} \beta$ production and clearance but also a transient infection may lead to a self-perpetuating innate immune response.

These findings allow an update of the hypothesis made in the JNT 2009 [84] (see Figure 1).

\section{Acknowledgments}

This work was supported by Grants from Ricerca Corrente, Italian Ministry of Health; AFaR; Fondazione CARIPLO 2009-2633.

\section{References}

[1] C. L. Masters, G. Simms, N. A. Weinman, G. Multhaup, B. L. McDonald, and K. Beyreuther, "Amyloid plaque core protein in Alzheimer disease and Down syndrome," Proceedings of the National Academy of Sciences of the United States of America, vol. 82, no. 12, pp. 4245-4249, 1985.

[2] J. Hardy and D. J. Selkoe, "The amyloid hypothesis of Alzheimer's disease: progress and problems on the road to therapeutics," Science, vol. 297, no. 5580, pp. 353-356, 2002.

[3] C. A. Lemere and E. Masliah, "Can Alzheimer disease be prevented by amyloid- $\beta$ immunotherapy?" Nature Reviews Neurology, vol. 6, no. 2, pp. 108-119, 2010.

[4] C. Haass, M. G. Schlossmacher, A. Y. Hung et al., "Amyloid $\beta$-peptide is produced by cultured cells during normal metabolism," Nature, vol. 359, no. 6393, pp. 322-325, 1992.

[5] T. C. Saido, T. Iwatsubo, D. M. A. Mann, H. Shimada, Y. Ihara, and S. Kawashima, "Dominant and differential deposition of distinct $\beta$-amyloid peptide species, $\mathrm{A} \beta \mathrm{N} 3(\mathrm{pE})$, in senile plaques," Neuron, vol. 14, no. 2, pp. 457-466, 1995.

[6] T. Iwatsubo, T. C. Saido, D. M. A. Mann, V. M. Y. Lee, and J. Q. Trojanowski, "Full-length amyloid- $\beta(1-42(43))$ and amino-terminally modified and truncated amyloid- $\beta 42(43)$ deposit in diffuse plaques," American Journal of Pathology, vol. 149, no. 6, pp. 1823-1830, 1996.

[7] C. Russo, T. C. Saido, L. M. DeBusk, M. Tabaton, P. Gambetti, and J. K. Teller, "Heterogeneity of water-soluble amyloid $\beta$ peptide in Alzheimer's disease and Down's syndrome brains," FEBS Letters, vol. 409, no. 3, pp. 411-416, 1997.

[8] C. Russo, G. Schettini, T. C. Saido et al., "Presenilin-1 mutations in Alzheimer's disease," Nature, vol. 405, no. 6786, pp. 531-532, 2000.

[9] E. Portelius, N. Bogdanovic, M. K. Gustavsson et al., "Mass spectrometric characterization of brain amyloid beta isoform signatures in familial and sporadic Alzheimer's disease," Acta Neuropathologica, vol. 120, no. 2, pp. 185-193, 2010.

[10] C. Russo, S. Salis, V. Dolcini et al., "Amino-terminal modification and tyrosine phosphorylation of carboxy-terminal fragments of the amyloid precursor protein in Alzheimer's disease and Down's syndrome brain," Neurobiology of Disease, vol. 8, no. 1, pp. 173-180, 2001.

[11] N. Sergeant, S. Bombois, A. Ghestem et al., "Truncated betaamyloid peptide species in pre-clinical Alzheimer's disease as new targets for the vaccination approach," Journal of Neurochemistry, vol. 85, no. 6, pp. 1581-1591, 2003.

[12] K. Liu, I. Solano, D. Mann et al., "Characterization of Abeta11-40/42 peptide deposition in Alzheimer's disease and young Down's syndrome brains: implication of N-terminally truncated Abeta species in the pathogenesis of Alzheimer's disease," Acta neuropathologica, vol. 112, no. 2, pp. 163-174, 2006.

[13] S. S. Sisodia, " $\beta$-Amyloid precursor protein cleavage by a membrane-bound protease," Proceedings of the National Academy of Sciences of the United States of America, vol. 89, no. 13, pp. 6075-6079, 1992.

[14] R. Vassar, B. D. Bennett, S. Babu-Khan et al., " $\beta$-Secretase cleavage of Alzheimer's amyloid precursor protein by the transmembrane aspartic protease BACE," Science, vol. 286, no. 5440, pp. 735-741, 1999.

[15] K. Liu, R. W. Doms, and V. M. Y. Lee, "Glu11 site cleavage and $\mathrm{N}$-terminally truncated $\mathrm{A} \beta$ production upon BACE overexpression," Biochemistry, vol. 41, no. 9, pp. 3128-3136, 2002.

[16] E. Portelius, E. Price, G. Brinkmalm et al., "A novel pathway for amyloid precursor protein processing," Neurobiology of Aging, vol. 32, no. 6, pp. 1090-1098, 2009.

[17] F. Kametani, " $\varepsilon$-secretase: reduction of amyloid precursor protein $\varepsilon$-site cleavage in Alzheimer's disease," Current Alzheimer Research, vol. 5, no. 2, pp. 165-171, 2008.

[18] E. Portelius, B. Zhang, M. K. Gustavsson et al., "Effects of $\gamma$-secretase inhibition on the amyloid $\beta$ isoform pattern in a mouse model of Alzheimer's disease," Neurodegenerative Diseases, vol. 6, no. 5-6, pp. 258-262, 2009.

[19] G. McKhann, D. Drachman, and M. Folstein, "Clinical diagnosis of Alzheimer's disease: report of the NINCDS-ADRDA work group under the auspices of Department of Health and Human Services Task Force on Alzheimer's disease," Neurology, vol. 34, no. 7, pp. 939-944, 1984.

[20] B. Dubois, H. H. Feldman, C. Jacova et al., "Research criteria for the diagnosis of Alzheimer's disease: revising the NINCDS-ADRDA criteria," Lancet Neurology, vol. 6, no. 8, pp. 734-746, 2007.

[21] B. Dubois, H. H. Feldman, C. Jacova et al., "Revising the definition of Alzheimer's disease: a new lexicon," The Lancet Neurology, vol. 9, no. 11, pp. 1118-1127, 2010.

[22] G. M. McKhann, D. S. Knopman, H. Chertkow et al., "The diagnosis of dementia due to Alzheimer's disease: recommendations from the National Institute on Aging-Alzheimer's Association workgroups on diagnostic guidelines for Alzheimer's disease," Alzheimer's and Dementia, vol. 7, no. 3, pp. 263-269, 2011.

[23] M. S. Albert, S. T. DeKosky, D. Dickson et al., "The diagnosis of mild cognitive impairment due to Alzheimer's disease: recommendations from the National Institute on Aging-Alzheimer's Association workgroups on diagnostic guidelines for Alzheimer's disease," Alzheimer's and Dementia, vol. 7, no. 3, pp. 270-279, 2011.

[24] R. A. Sperling, P. S. Aisen, L. A. Beckett et al., "Toward defining the preclinical stages of Alzheimer's disease: recommendations from the National Institute on Aging-Alzheimer's Association workgroups on diagnostic guidelines for Alzheimer's disease," Alzheimer's and Dementia, vol. 7, no. 3, pp. 280-292, 2011.

[25] K. Blennow, H. Hampel, M. Weiner, and H. Zetterberg, "Cerebrospinal fluid and plasma biomarkers in Alzheimer disease," Nature Reviews Neurology, vol. 6, no. 3, pp. 131-144, 2010 . 
[26] N. Mattsson, H. Zetterberg, O. Hansson et al., "CSF biomarkers and incipient Alzheimer disease in patients with mild cognitive impairment," Journal of the American Medical Association, vol. 302, no. 4, pp. 385-393, 2009.

[27] P. J. Visser, F. Verhey, D. L. Knol et al., "Prevalence and prognostic value of CSF markers of Alzheimer's disease pathology in patients with subjective cognitive impairment or mild cognitive impairment in the DESCRIPA study: a prospective cohort study," The Lancet Neurology, vol. 8, no. 7, pp. 619627, 2009.

[28] L. M. Shaw, H. Vanderstichele, M. Knapik-Czajka et al., "Cerebrospinal fluid biomarker signature in alzheimer's disease neuroimaging initiative subjects," Annals of Neurology, vol. 65, no. 4, pp. 403-413, 2009.

[29] G. B. Frisoni, A. Prestia, O. Zanetti et al., "Markers of Alzheimer's disease in a population attending a memory clinic," Alzheimer's and Dementia, vol. 5, no. 4, pp. 307-317, 2009.

[30] S. Galluzzi, C. Geroldi, R. Ghidoni et al., "Translational outpatient memory clinic working group. The new Alzheimer's criteria in a naturalistic series of patients with mild cognitive impairment," Journal of Neurology, vol. 257, no. 12, pp. 20042014, 2010.

[31] M. Kanai, E. Matsubara, K. Isoe et al., "Longitudinal study of cerebrospinal fluid levels of tau, $\mathrm{A} \beta 1-40$, and $\mathrm{A} \beta 1-42(43)$ in Alzheimer's disease: a study in Japan," Annals of Neurology, vol. 44, no. 1, pp. 17-26, 1998.

[32] P. D. Mehta, T. Pirttilä, S. P. Mehta, E. A. Sersen, P. S. Aisen, and H. M. Wisniewski, "Plasma and cerebrospinal fluid levels of amyloid $\beta$ proteins 1-40 and 1- 42 in Alzheimer disease," Archives of Neurology, vol. 57, no. 1, pp. 100-105, 2000.

[33] R. Fukuyama, T. Mizuno, T. Mizuno et al., "Age-dependent change in the levels of $A \beta 40$ and $A \beta 42$ in cerebrospinal fluid from control subjects, and a decrease in the ratio of $\mathrm{A} \beta 42$ to A $\beta 40$ level in cerebrospinal fluid from Alzheimer's disease patients," European Neurology, vol. 43, no. 3, pp. 155-160, 2000.

[34] O. Hansson, H. Zetterberg, P. Buchhave et al., "Prediction of Alzheimer's disease using the CSF $A \beta 42 / A \beta 40$ ratio in patients with mild cognitive impairment," Dementia and Geriatric Cognitive Disorders, vol. 23, no. 5, pp. 316-320, 2007.

[35] A. M. Fagan, D. Head, A. R. Shah et al., "Decreased cerebrospinal fluid $\mathrm{A} \beta 42$ correlates with brain atrophy in cognitively normal elderly," Annals of Neurology, vol. 65, no. 2, pp. 176$183,2009$.

[36] C. M. Roe, A. M. Fagan, M. M. Williams et al., "Improving CSF biomarker accuracy in predicting prevalent and incident Alzheimer disease," Neurology, vol. 76, no. 6, pp. 501-510, 2011.

[37] S. Rolstad, A. I. Berg, M. Bjerke et al., "Amyloid- $\beta 42$ is associated with cognitive impairment in healthy elderly and subjective cognitive impairment," Journal of Alzheimer's Disease,. In press.

[38] A. Cedazo-Minguez and B. Winblad, "Biomarkers for Alzheimer's disease and other forms of dementia: clinical needs, limitations and future aspects," Experimental Gerontology, vol. 45, no. 1, pp. 5-14, 2010.

[39] M. Bibl, B. Mollenhauer, S. Wolf et al., "Reduced CSF carboxyterminally truncated $\mathrm{A} \beta$ peptides in frontotemporal lobe degenerations," Journal of Neural Transmission, vol. 114, no. 5, pp. 621-628, 2007.

[40] M. Bibl, B. Mollenhauer, H. Esselmann et al., "CSF diagnosis of Alzheimer's disease and dementia with Lewy bodies,"
Journal of Neural Transmission, vol. 113, no. 11, pp. 17711778, 2006.

[41] N. Andreasen and H. Zetterberg, "Amyloid-related biomarkers for Alzheimer's disease," Current Medicinal Chemistry, vol. 15, no. 8, pp. 766-771, 2008.

[42] E. Gowing, A. E. Roher, A. S. Woods et al., "Chemical characterization of $A \beta 17-42$ peptide, a component of diffuse amyloid deposits of Alzheimer disease," Journal of Biological Chemistry, vol. 269, no. 15, pp. 10987-10990, 1994.

[43] J. Näslund, A. Schierhorn, U. Hellman et al., "Relative abundance of Alzheimer A $\beta$ amyloid peptide variants in Alzheimer disease and normal aging," Proceedings of the National Academy of Sciences of the United States of America, vol. 91, no. 18 , pp. 8378-8382, 1994.

[44] Y. Harigaya, T. C. Saido, C. B. Eckman, C. M. Prada, M. Shoji, and S. G. Younkin, "Amyloid $\beta$ protein starting pyroglutamate at position 3 is a major component of the amyloid deposits in the Alzheimer's disease brain," Biochemical and Biophysical Research Communications, vol. 276, no. 2, pp. 422-427, 2000.

[45] L. Miravalle, M. Calero, M. Takao, A. E. Roher, B. Ghetti, and R. Vidal, "Amino-terminally truncated A $\beta$ peptide species are the main component of cotton wool plaques," Biochemistry, vol. 44, no. 32, pp. 10810-10821, 2005.

[46] A. Piccini, C. Russo, A. Gliozzi et al., " $\beta$-amyloid is different in normal aging and in Alzheimer disease," Journal of Biological Chemistry, vol. 280, no. 40, pp. 34186-34192, 2005.

[47] E. Portelius, A. Westman-Brinkmalm, H. Zetterberg, and K. Blennow, "Determination of $\beta$-amyloid peptide signatures in cerebrospinal fluid using immunoprecipitation-mass spectrometry," Journal of Proteome Research, vol. 5, no. 4, pp. 1010-1016, 2006.

[48] E. Portelius, A. J. Tran, U. Andreasson et al., "Characterization of amyloid $\beta$ peptides in cerebrospinal fluid by an automated immunoprecipitation procedure followed by mass spectrometry," Journal of Proteome Research, vol. 6, no. 11, pp. 4433-4439, 2007.

[49] E. Portelius, U. Andreasson, J. M. Ringman et al., "Distinct cerebrospinal fluid amyloid peptide signatures in sporadic and PSEN1 A431E-associated familial Alzheimer's disease," Molecular Neurodegeneration, vol. 5, no. 1, article 2, 2010.

[50] A. S. Maddalena, A. Papassotiropoulos, C. Gonzalez-Agosti et al., "Cerebrospinal fluid profile of amyloid $\beta$ peptides in patients with Alzheimer's disease determined by protein biochip technology," Neurodegenerative Diseases, vol. 1, no. 4-5, pp. 231-235, 2004.

[51] V. Albertini, A. Bruno, A. Paterlini et al., "Optimization protocol for amyloid- $\beta$ peptides detection in human cerebrospinal fluid using SELDI TOF MS," Proteomics - Clinical Applications, vol. 4, no. 3, pp. 352-357, 2010.

[52] E. Portelius, H. Zetterberg, U. Andreasson et al., "An Alzheimer's disease-specific $\beta$-amyloid fragment signature in cerebrospinal fluid," Neuroscience Letters, vol. 409, no. 3, pp. 215-219, 2006.

[53] C. Vigo-Pelfrey, D. Lee, P. Keim, I. Lieberburg, and D. B. Schenk, "Characterization of $\beta$-amyloid peptide from human cerebrospinal fluid," Journal of Neurochemistry, vol. 61, no. 5, pp. 1965-1968, 1993.

[54] R. Ghidoni, V. Albertini, R. Squitti et al., "Novel T719P A $\beta$ PP mutation unbalances the relative proportion of amyloid$\beta$ peptides," Journal of Alzheimer's Disease, vol. 18, no. 2, pp. 295-303, 2009. 
[55] P. Lewczuk, H. Esselmann, M. Meyer et al., "The amyloid$\beta(\mathrm{A} \beta)$ peptide pattern in cerebrospinal fluid in Alzheimer's disease: evidence of a novel carboxyterminally elongated A $\beta$ peptide," Rapid Communications in Mass Spectrometry, vol. 17, no. 12, pp. 1291-1296, 2003.

[56] H. Vanderstichele, G. De Meyer, N. Andreasen et al., "Aminotruncated $\beta$-amyloid42 peptides in cerebrospinal fluid and prediction of progression of mild cognitive impairment," Clinical Chemistry, vol. 51, no. 9, pp. 1650-1660, 2005.

[57] J. Wiltfang, H. Esselmann, M. Bibl et al., "Highly conserved and disease-specific patterns of carboxyterminally truncated A $\beta$ peptides 1-37/38/39 in addition to 1-40/42 in Alzheimer's disease and in patients with chronic neuroinflammation," Journal of Neurochemistry, vol. 81, no. 3, pp. 481-496, 2002.

[58] P. Lewczuk, H. Esselmann, T. W. Groemer et al., "Amyloid $\beta$ peptides in cerebrospinal fluid as profiled with surface enhanced laser desorption/ionization time-of-flight mass spectrometry: evidence of novel biomarkers in Alzheimer's disease," Biological Psychiatry, vol. 55, no. 5, pp. 524-530, 2004.

[59] E. Portelius, R. A. Dean, M. K. Gustavsson et al., "A novel abeta isoform pattern in CSF reflects gamma-secretase inhibition in Alzheimer disease," Alzheimer's Research \& Theraphy, vol. 2, no. 7, pp. 1-7, 2010.

[60] D. M. Walsh and D. J. Selkoe, "A $\beta$ oligomers-a decade of discovery," Journal of Neurochemistry, vol. 101, no. 5, pp. 1172-1184, 2007.

[61] W. Xia, T. Yang, G. Shankar et al., "A specific enzyme-linked immunosorbent assay for measuring $\beta$-amyloid protein oligomers in human plasma and brain tissue of patients with Alzheimer Disease," Archives of Neurology, vol. 66, no. 2, pp. 190-199, 2009.

[62] M. P. Lambert, A. K. Barlow, B. A. Chromy et al., "Diffusible, nonfibrillar ligands derived from A $\beta 1-42$ are potent central nervous system neurotoxins," Proceedings of the National Academy of Sciences of the United States of America, vol. 95, no. 11, pp. 6448-6453, 1998.

[63] D. M. Hartley, D. M. Walsh, C. P. Ye et al., "Protofibrillar intermediates of amyloid $\beta$-protein induce acute electrophysiological changes and progressive neurotoxicity in cortical neurons," Journal of Neuroscience, vol. 19, no. 20, pp. 8876 8884, 1999.

[64] R. Kayed, Y. Sokolov, B. Edmonds et al., "Permeabilization of lipid bilayers is a common conformation-dependent activity of soluble amyloid oligomers in protein misfolding diseases," Journal of Biological Chemistry, vol. 279, no. 45, pp. 4636346366, 2004.

[65] L. Mucke, E. Masliah, G. Q. Yu et al., "High-level neuronal expression of $A \beta(1-42)$ in wild-type human amyloid protein precursor transgenic mice: synaptotoxicity without plaque formation," Journal of Neuroscience, vol. 20, no. 11, pp. 4050 4058, 2000.

[66] S. Lesné, T. K. Ming, L. Kotilinek et al., "A specific amyloid$\beta$ protein assembly in the brain impairs memory," Nature, vol. 440, no. 7082, pp. 352-357, 2006.

[67] D. M. Walsh, I. Klyubin, J. V. Fadeeva et al., "Naturally secreted oligomers of amyloid $\beta$ protein potently inhibit hippocampal long-term potentiation in vivo," Nature, vol. 416, no. 6880 , pp. 535-539, 2002.

[68] I. Klyubin, D. M. Walsh, C. A. Lemere et al., "Amyloid $\beta$ protein immunotherapy neutralizes $\mathrm{A} \beta$ oligomers that disrupt synaptic plasticity in vivo," Nature Medicine, vol. 11, no. 5, pp. 556-561, 2005.
[69] G. M. Shankar, S. Li, T. H. Mehta et al., "Amyloid- $\beta$ protein dimers isolated directly from Alzheimer's brains impair synaptic plasticity and memory," Nature Medicine, vol. 14, no. 8, pp. 837-842, 2008.

[70] M. N. Reed, J. J. Hofmeister, L. Jungbauer et al., "Cognitive effects of cell-derived and synthetically derived Abeta oligomers," Neurobiology of Aging, vol. 32, no. 10, pp. 17841794, 2011.

[71] S. Li, M. Jin, T. Koeglsperger, N. E. Shepardson, G. M. Shankar, and D. J. Selkoe, "Soluble a $\beta$ oligomers inhibit longterm potentiation through a mechanism involving excessive activation of extrasynaptic NR2B-containing NMDA receptors," Journal of Neuroscience, vol. 31, no. 18, pp. 6627-6638, 2011.

[72] M. Pitschke, R. Prior, M. Haupt, and D. Riesner, "Detection of single amyloid $\beta$-protein aggregates in the cerebrospinal fluid of Alzheirner's patients by fluorescence correlation spectroscopy," Nature Medicine, vol. 4, no. 7, pp. 832-834, 1998.

[73] D. G. Georganopoulou, L. Chang, J. M. Nam et al., "Nanoparticle-based detection in cerebral spinal fluid of a soluble pathogenic biomarker for Alzheimer's disease," Proceedings of the National Academy of Sciences of the United States of America, vol. 102, no. 7, pp. 2273-2276, 2005.

[74] A. N. Santos, S. Torkler, D. Nowak et al., "Detection of amyloid- $\beta$ oligomers in human cerebrospinal fluid by flow cytometry and fluorescence resonance energy transfer," Journal of Alzheimer's Disease, vol. 11, no. 1, pp. 117-125, 2007.

[75] I. Klyubin, V. Betts, A. T. Welzel et al., "Amyloid $\beta$ protein dimer-containing human CSF disrupts synaptic plasticity: prevention by systemic passive immunization," Journal of Neuroscience, vol. 28, no. 16, pp. 4231-4237, 2008.

[76] H. Englund, M. D. Gunnarsson, R. M. Brundin et al., "Oligomerization partially explains the lowering of $A \beta 42$ in alzheimer's disease cerebrospinal fluid," Neurodegenerative Diseases, vol. 6, no. 4, pp. 139-147, 2009.

[77] H. Fukumoto, T. Tokuda, T. Kasai et al., "High-molecularweight beta-amyloid oligomers are elevated in cerebrospinal fluid of Alzheimer patients," The Journal the Federation of American Societies for Experimental Biology, vol. 24, no. 8, pp. 2716-2726, 2010.

[78] C. M. Gao, A. Y. Yam, E. Magdangal et al., "A $\beta 40$ oligomers identified as a potential biomarker for the diagnosis of alzheimer's disease," PLoS One, vol. 5, no. 12, Article ID e15725, 2010.

[79] R. Kayed, E. Head, J. L. Thompson et al., "Common structure of soluble amyloid oligomers implies common mechanism of pathogenesis," Science, vol. 300, no. 5618, pp. 486-489, 2003.

[80] B. O’Nuallain and R. Wetzel, "Conformational Abs recognizing a generic amyloid fibril epitope," Proceedings of the National Academy of Sciences of the United States of America, vol. 99, no. 3, pp. 1485-1490, 2002.

[81] M. P. Lambert, P. T. Velasco, L. Chang et al., "Monoclonal antibodies that target pathological assemblies of A $\beta$," Journal of Neurochemistry, vol. 100, no. 1, pp. 23-35, 2007.

[82] G. Habicht, C. Haupt, R. P. Friedrich et al., "Directed selection of a conformational antibody domain that prevents mature amyloid fibril formation by stabilizing $\mathrm{A} \beta$ protofibrils," Proceedings of the National Academy of Sciences of the United States of America, vol. 104, no. 49, pp. 19232-19237, 2007.

[83] G. Meli, M. Visintin, I. Cannistraci, and A. Cattaneo, "Direct in vivo intracellular selection of conformation-sensitive antibody domains targeting Alzheimer's amyloid- $\beta$ oligomers," 
Journal of Molecular Biology, vol. 387, no. 3, pp. 584-606, 2009.

[84] L. F. Agnati, G. Leo, S. Genedani et al., "Common key-signals in learning and neurodegeneration: focus on excito-amino acids, $\beta$-amyloid peptides and $\alpha$-synuclein," Journal of Neural Transmission, vol. 116, no. 8, pp. 953-974, 2009.

[85] L. F. Agnati and K. Fuxe, "Volume transmission as a key feature of information handling in the central nervous system possible new interpretative value of the Turing's B-type machine," Progress in Brain Research, vol. 125, pp. 3-19, 2000.

[86] A. Lakkaraju and E. Rodriguez-Boulan, "Itinerant exosomes: emerging roles in cell and tissue polarity," Trends in Cell Biology, vol. 18, no. 5, pp. 199-209, 2008.

[87] E. Cocucci, G. Racchetti, and J. Meldolesi, "Shedding microvesicles: artefacts no more," Trends in Cell Biology, vol. 19, no. 2, pp. 43-51, 2009.

[88] M. Simons and G. Raposo, "Exosomes—-vesicular carriers for intercellular communication," Current Opinion in Cell Biology, vol. 21, no. 4, pp. 575-581, 2009.

[89] A. Rustom, "Hen or egg? Some thoughts on tunneling nanotubes," Annals of the New York Academy of Sciences, vol. 1178, pp. 129-136, 2009.

[90] L. F. Agnati, S. Genedani, G. Leo et al., “A $\beta$ peptides as one of the crucial volume transmission signals in the trophic units and their interactions with homocysteine. Physiological implications and relevance for Alzheimer's disease," Journal of Neural Transmission, vol. 114, no. 1, pp. 21-31, 2007.

[91] K. Vekrellis, Z. Ye, W. Q. Qiu et al., "Neurons regulate extracellular levels of amyloid $\beta$-protein via proteolysis by insulindegrading enzyme," Journal of Neuroscience, vol. 20, no. 5, pp. 1657-1665, 2000.

[92] C. Hock, S. Golombowski, F. Müller-Spahn et al., "Cerebrospinal fluid levels of amyloid precursor protein and amyloid $\beta$-peptide in Alzheimer's disease and major depressioninverse correlation with dementia severity," European Neurology, vol. 39, no. 2, pp. 111-118, 1998.

[93] S. A. Funke, E. Birkmann, and D. Willbold, "Detection of amyloid- $\beta$ aggregates in body fluids: a suitable method for early diagnosis of Alzheimer's disease?" Current Alzheimer Research, vol. 6, no. 3, pp. 285-289, 2009.

[94] T. Oe, B. L. Ackermann, K. Inoue et al., "Quantitative analysis of amyloid $\beta$ peptides in cerebrospinal fluid of Alzheimer's disease patients by immunoaffinity purification and stable isotope dilution liquid chromatography/negative electrospray ionization tandem mass spectrometry," Rapid Communications in Mass Spectrometry, vol. 20, no. 24, pp. 37233735, 2006.

[95] L. Rajendran, M. Honsho, T. R. Zahn et al., “Alzheimer's disease $\beta$-amyloid peptides are released in association with exosomes," Proceedings of the National Academy of Sciences of the United States of America, vol. 103, no. 30, pp. 1117211177, 2006.

[96] V. Vingtdeux, M. Hamdane, A. Loyens et al., "Alkalizing drugs induce accumulation of amyloid precursor protein byproducts in luminal vesicles of multivesicular bodies," Journal of Biological Chemistry, vol. 282, no. 25, pp. 18197-18205, 2007.

[97] R. A. Sharples, L. J. Vella, R. M. Nisbet et al., "Inhibition of $\gamma$-secretase causes increased secretion of amyloid precursor protein C-terminal fragments in association with exosomes," The Journal of the Federation of American Societies for Experimental Biology, vol. 22, no. 5, pp. 1469-1478, 2008.
[98] R. Ghidoni, L. Benussi, and G. Binetti, "Exosomes: the Trojan horses of neurodegeneration," Medical Hypotheses, vol. 70, no. 6, pp. 1226-1227, 2008.

[99] R. Ghidoni, A. Paterlini, V. Albertini et al., "Cystatin C is released in association with exosomes: a new tool of neuronal communication which is unbalanced in Alzheimer's disease," Neurobiology of Aging, vol. 32, no. 8, pp. 1435-1442, 2009.

[100] L. F. Agnati, D. Guidolin, F. Baluka et al., "A new hypothesis of pathogenesis based on the divorce between mitochondria and their host cells: possible relevance for alzheimer's disease," Current Alzheimer Research, vol. 7, no. 4, pp. 307-322, 2010.

[101] E. Y. Chi, S. L. Frey, and K. Y. C. Lee, "Ganglioside GM1-mediated amyloid-beta fibrillogenesis and membrane disruption," Biochemistry, vol. 46, no. 7, pp. 1913-1924, 2007.

[102] K. Yuyama, N. Yamamoto, and K. Yanagisawa, "Accelerated release of exosome associated GM1 ganglioside (GM1) by endocytic pathway abnormality: another putative pathway for GM1-induced amyloid fibril formation," Journal of Neurochemistry, vol. 105, no. 1, pp. 217-224, 2008.

[103] R. N. Re and J. L. Cook, "Senescence, apoptosis, and stem cell biology: the rationale for an expanded view of intracrine action," American Journal of Physiology, Heart and Circulatory Physiology, vol. 297, no. 3, pp. H893-H901, 2009.

[104] A. Y. Lai and J. McLaurin, "Mechanisms of amyloid-beta peptide uptake by neurons: the role of lipid rafts and lipid raft-associated proteins," International Journal of Alzheimer's Disease, vol. 2011, Article ID 548380, 11 pages, 2011.

[105] H. A. Pearson and C. Peers, "Physiological roles for amyloid $\beta$ peptides," Journal of Physiology, vol. 575, no. 1, pp. 5-10, 2006.

[106] A. Garcia-Osta and C. M. Alberini, "Amyloid beta mediates memory formation," Neurobiology of Learning and Memory, vol. 16, no. 4, pp. 267-272, 2009.

[107] S. J. Soscia, J. E. Kirby, K. J. Washicosky et al., "The Alzheimer's disease-associated amyloid $\beta$-protein is an antimicrobial peptide," PLoS One, vol. 5, no. 3, Article ID e9505, pp. 1-10, 2010.

[108] E. Tanzi, "I fatti e le induzione nell'odierna istologia del sistema nervoso," Rivista sperimentale di freniatria e medicina legale delle alienazioni mentali, vol. 19, pp. 419-472, 1893.

[109] J. S. Taylor and R. M. Gaze, "The effects of the fibre environment on the paths taken by regenerating optic nerve fibres in Xenopus," Journal of Embryology and Experimental Morphology, vol. 89, pp. 383-401, 1985.

[110] L. F. Agnati, M. Zoli, G. Biagini, and K. Fuxe, "Neuronal plasticity and ageing processes in the frame of the 'Red Queen Theory," Acta Physiologica Scandinavica, vol. 145, no. 4, pp. 301-309, 1992.

[111] K. Yamada and T. Nabeshima, "Brain-derived neurotrophic factor/TrkB signaling in memory processes," Journal Pharmacological Sciences, vol. 91, no. 4, pp. 267-270, 2003.

[112] K. Schindowski, K. Belarbi, and L. Buée, "Neurotrophic factors in Alzheimer's disease: role of axonal transport," Genes, Brain and Behavior, vol. 7, no. 1, pp. 43-56, 2008.

[113] E. E. Tuppo and H. R. Arias, "The role of inflammation in Alzheimer's disease," International Journal of Biochemistry and Cell Biology, vol. 37, no. 2, pp. 289-305, 2005. 

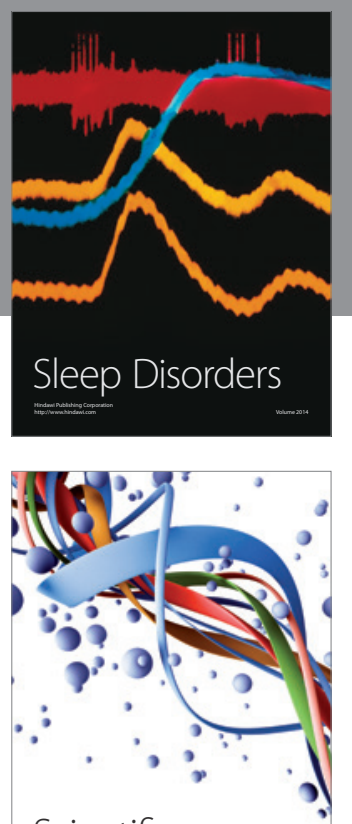

Scientifica
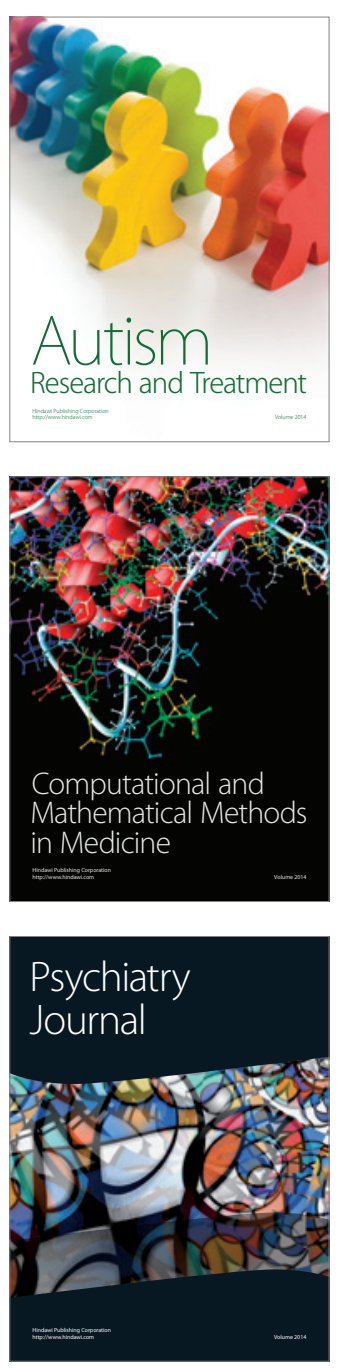
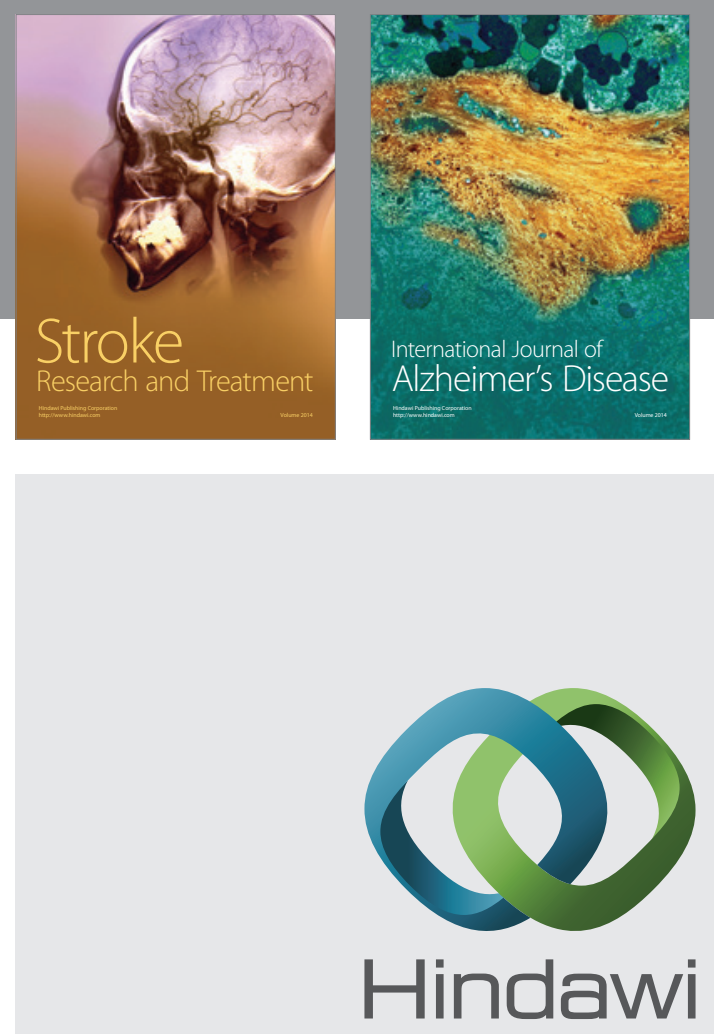

Submit your manuscripts at

http://www.hindawi.com
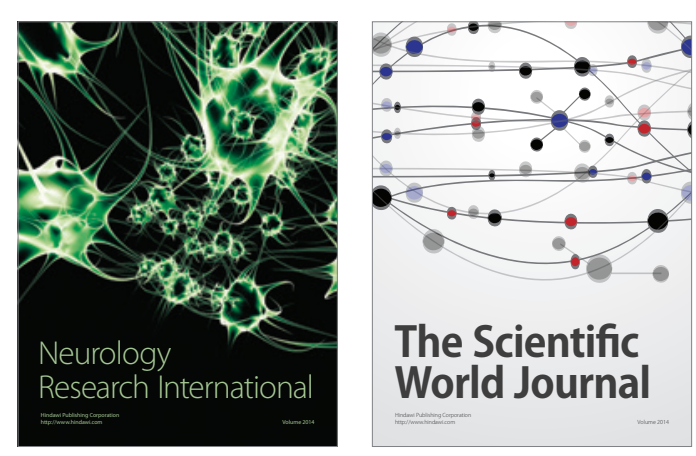

The Scientific World Journal

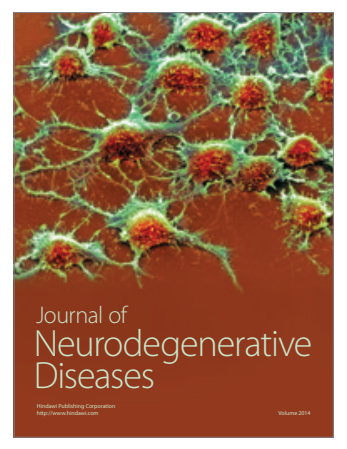

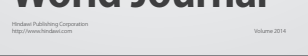

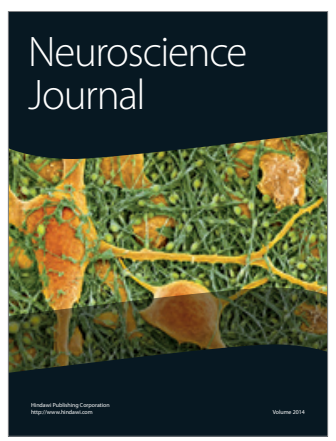

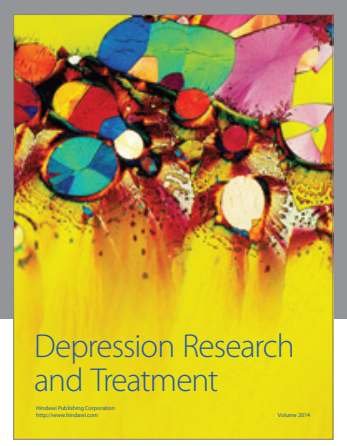
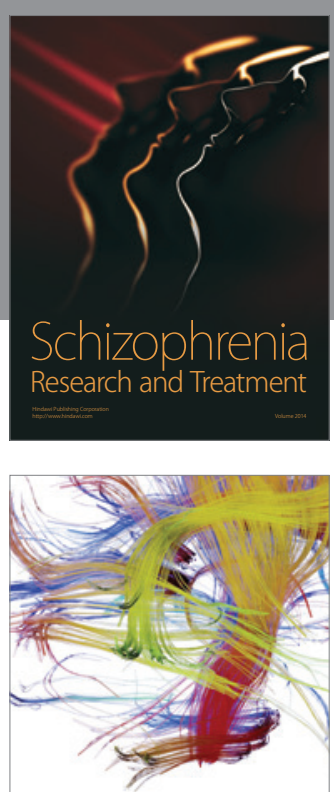

Brain Science

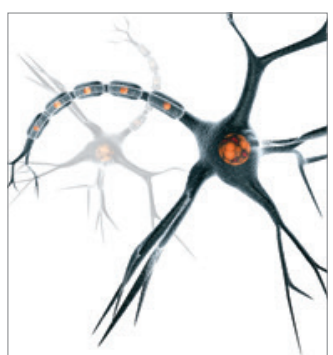

Neural Plasticity
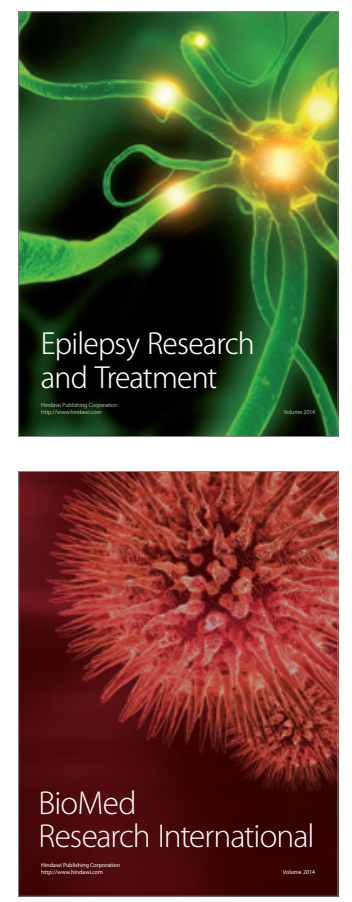

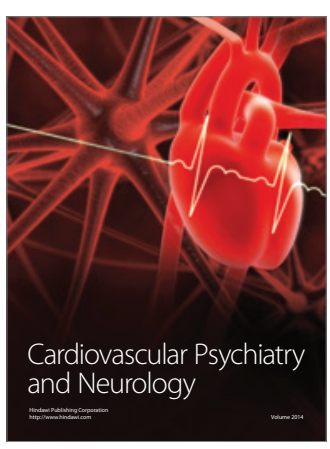

Parkinson's

Disease
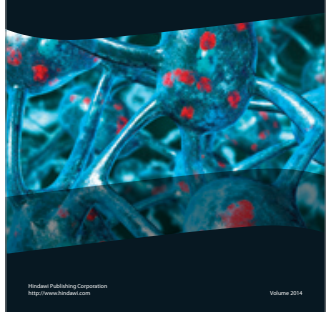